\title{
Animeldelse:
}

\section{Med Danmarks børn i hellig krig}

\section{Af Mads Nørgaard-Larsen}

Jakob Sheikh giver os en unik adgang til Danmarks militante islamistiske miljø og et nuanceret indblik i historierne om de børn, der blev forført af tanken om hellig krig.

Jakob Sheikh: Danmarks børn i hellig krig. Lindhardt og Ringhof, 2015, 567 s.

Politiken-journalisten Jakob Sheikh undersøger i denne bog et af tidens mest presserende spørgsmål: hvad, der får almindelige unge danske muslimer, oftest født og opvokset her i landet, til at bekende sig til militant islamisme og hellig krig, og hvorfor de, alt imens mange syrere og irakere ankommer til Europa på flugt fra krigens rædsler, vælger at rejse den modsatte vej - for at kæmpe for ekstreme og militante islamistiske grupperinger og for realiseringen af en islamisk kalifat-stat.

Bogen skildrer en række unge danske muslimers vej ind i militant islamistisk radikalisering og hellig krig. Vi følger deres rejse fra en religiøs vækkelse til en tilværelse i Danmarks mest ekstreme islamistiske miljø, og vi er med, når det politisk-religiøse engagement kammer over i forsøg på ekstremistiske handlinger, hovedroller i de største danske terrorsager eller i hellig krig i Syrien og Irak.

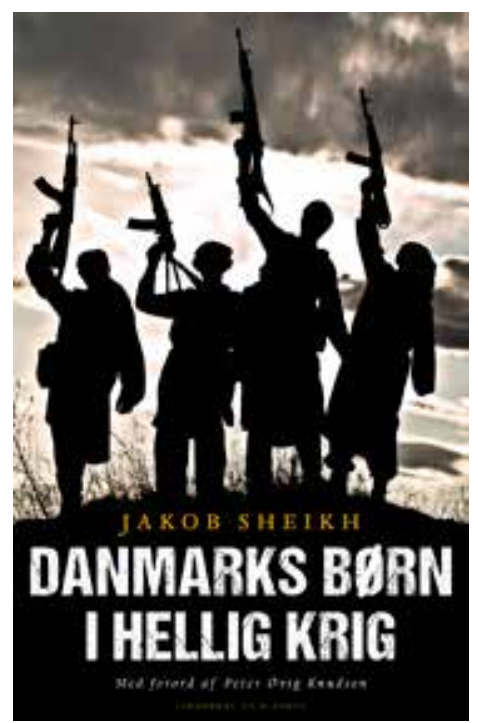

Jakob Sheikh skriver sig med denne bog uvægerligt ind i den løbende diskussion om radikaliseringens årsager og virkninger, når han dykker ned i hovedpersonernes liv og kulegraver det militante islamistiske miljø, som hurtigt bliver de unges andet hjem.

Selv om fænomenet radikalisering, her med islamistisk fortegn, de sidste år har stået højt på den politiske dagsorden i Europa og har været genstand for megen debat, så er det stadig uhyre svært at forklare, hvorfor processen sker - og

Mads Nørgaard-Larsen er uddannet journalist og cand.mag. i moderne mellemøststudier. 
for hvem. Alligevel formår Jakob Sheikh med sin bog at sætte fingeren på flere af de især sociale, men også politiske og religiøse, forhold, som gør søgende, usikre og fremmedgjorte unge mænd og kvinder sårbare for ekstremistisk påvirkning.

Et særligt kritisk blik kaster Sheikh på det radikale islamistiske miljø i Danmark og på centrale figurer, grupperinger og mødesteder, som har spillet en stor rolle $\mathrm{i}$ indpodningen af unge letpåvirkelige mennesker med ekstreme tanker om hellig krig.

\section{En lukket verden}

Det er et skræmmende indblik i en ellers ofte lukket verden, som Jakob Sheikh giver os. Som journalist på Politiken har han de seneste år primært beskæftiget sig med stofområderne radikalisering, terror og konflikterne i Mellemøsten, og det kommer i den grad læserne af hans bog til gode. Han ved ganske enkelt, hvad han snakker om - både hvad angår radikalisering, ekstreme islamistiske miljøer i Danmark og Europa og den tumultariske politiske udvikling i Mellemøsten, som flere af hovedpersonerne i bogen med deres skæbnesvangre valg ender med at opsøge og smelte sammen med.

Jakob Sheikhs arbejde udmærker sig i høj grad ved den unikke adgang til de lukkede cirkler i det yderligtgående islamistiske miljø og til flere danske 'fremmedkrigere'.

Kildematerialet for denne bog, som blandt andet tæller hundredvis af interviews med toneangivende personer i det militante islamistiske miljø, flere af krigerne selv, forældre og venner, samt politi-, efterretnings- og myndighedskilder, er intet mindre end imponerende, og det er i høj grad dette kildemateriale, som gør Sheikh i stand til med stor indlevelse og detaljerigdom at kortlægge de unges vej ind i radikaliseringen og deres færden i Danmarks radikale islamistiske underverden og i Syrien og Irak.

Især beskrivelserne af det militante islamistiske miljø giver læserne et sjældent både fascinerende og urovækkende indblik i den verden, som hovedpersonerne blev en del af, hvor de blev ideologisk formet, og hvor de hentede deres udenlandske kontakter.

En central figur i bogens udredning af dette islamistiske miljø, som Jakob Sheikh kalder 'Edderkoppen', spiller en hovedrolle som bagmand og 'radikalisator' - en særligt karismatisk mand med en uhyggelig evne til at indpode unge følgere med en militant salafistisk ideologi, og hvis indflydelse kan aflæses i det spor af unge terrordømte - og mistænkte muslimer og hellige krigere, som han trækker efter sig.

Det er decideret hjerteskærende at følge, hvordan de søgende unge, som vi møder, der mest af alt leder efter en vej i livet, et formål og et sted at høre til, kan blive ofre for radikaliserende ideologer, som trin for trin manipulerer dem ind $\mathrm{i}$ ekstremismen. Få vil ikke også blive berørt af at læse, hvordan de unges forældre langsomt mister grebet om deres børn. Som læser aner man jo, hvor det ender, og at det ikke er godt.

\section{Et menneskeligt billede}

Igennem hele bogen formår Jakob Sheikh at gøre noget, synes jeg, meget prisværdigt: at fremkalde et billede af hovedpersonerne som mennesker. Deres liv bliver beskrevet med en empati, som aldrig kammer over i pladderhumanistisk 'overforståelse', men som vidner om, at han oprigtigt har forsøgt at sætte sig i deres sted og at forstå baggrunden for hver de- 
res radikale transformation og senere skæbnesvangre valg.

Hvis vi i fremtiden som samfund skal gøre os håb om at bremse problemerne med unges radikalisering, så er den slags åbne, nysgerrige og fordomsfri tilgange vigtige.

Som Peter Øvig Knudsen skriver i forordet, der drager paralleller til hans eget arbejde med fanatismen, Blekingegadebandens militante marxisme, finder man i Jakob Sheikhs bog "ikke nogen enkle forklaringer, formler eller nemme løsninger" - man finder "kompleksiteten". Bogen peger med sine grundige dyk ned i unge, ulykkelige menneskeskæbner på, hvordan mange forskellige livssituationer og faktorer kan igangsætte en ung persons vej ind i et radikaliserende miljø og svække hans, eller hendes, modstandskraft over for de personer, som forsøger at påvirke dem ideologisk.

Alligevel, eller måske netop derfor, er Sheikhs kortlægning af Danmarks unge børn i hellig krig og kulegravningen af det radikale islamistiske miljø et vigtigt bidrag til den samfundsopgave, det er at forstå radikaliseringen, så vi bedre kan bekæmpe den. 